\title{
DEVELOPMENT OF IMMUNITY AGAINST TRICHOPHYTOSIS AFTER EPICUTANEOUS ADMINISTRATION OF AN AVIRULENT TRICHOPHYTON VERRUCOSUM STRAIN
}

\author{
A. RYBNIKÁR \\ Bioveta, 68323 Ivanovice na Hané
}

Received July 20, 1993

\begin{abstract}
Rybnikár A.: Development of Immunity against Trichophytosis after Epicutaneous Administration of an Avirulent Trichophyton verrucosum Strain. Acta vet. Brno, 63, 1994: 61-64.

Epicutaneous inoculation of calves with an avirulent Trichophyton verrucosum strain onto the clipped scarified or even non-scarified skin in two doses conferred immunity against experimental infection with the virulent strain of the same species. Where the immunogenic $T$. verrucosum culture was rubbed onto hair of the non-clipped skin no satisfactory protection was obtained.
\end{abstract}

Dermatophytes, epicutaneous immunization, challenge

Experimental infection of animals with dermatophyte cultures was reported to produce resistance to reinfection at the beginning of this century (B loch and M a s sin i 1909). The problems of immunity after experimental and natural dermatophytosis were then studied by a number of other writers (G r a p pel et al. 1974; W ei 1 1 1987). The question whether immunity can also be produced by epicutaneous administration of an avirulent dermatophyte strains has not been investigated in detail to date. Some observations made in our experiments with an avirulent Trichophyton verrucosum strain are reported in the present study.

\section{Materials and Methods}

The experimental animals were calves of the Bohemian Pied Breed from herds without a history of trichophytosis. At 4 to 6 weeks of age they were inoculated epicutaneously with a living avirulent culture of Trichophyton verrucosum CCM F-751 (=TV-M-9) on two occasions 10 days apart. The CCM F-751 mutant was prepared from the fully virulent $T$. verrucosum strain using UV-radiation (H e j t mán e $\mathrm{k}$ et al. 1986). The inoculation was carried out by rubbing a suspension of the culture onto a $10 \times 10 \mathrm{~cm}$ area of

a) clipped and scarified skin,

b) clipped non-scarified skin,

c) non-clipped hair of the right flank.

One inoculation dose contained 12 million conidia of the avirulent strain. Thirty-two days after the second administration of the avirulent strain the immunized calves and non-immunized controls were challenged by epicutaneous inoculation of the virulent $T$. verrucosum strain onto the clipped and gently scarified skin at the rate of 5 million conidia per animal. The inoculation site was either the same as that used for administration of the avirulent culture or a $10 \times 10 \mathrm{~cm}$ area on the opposite side of the body (left flank). The animals were observed for possible clinical dermal changes at the challenge site for 33 days after challenge. At the end of the experiment the dermal lesions were examined microscopically and by culture (Rybnikár 1992).

\section{Results}

After inoculation of the calves with avirulent $T$. verrucosum strain CCM F-751 no trichophytic lesions were observed. Only in a few animals minute superficial scales were seen at the inoculation site, coming off within 7 to 10 days.

The survey of dermal changes observed after challenge is presented in Tables 1 and 2. It can be seen that calves inoculated with avirulent CCM F-751 strain onto clipped skin developed immunity against the virulent $T$. verrucosum strain. Whereas non-immunized controls showed deep trichophytic lesions at the inoculation site of the challenge culture, the groups of calves immunized by inoculation onto clipped skin (whether scarified or non-scarified) exhibited only superficial post-challenge changes of short duration. The results were practically the same whether the challenge inoculum was administered onto the same site as was 
used for immunization or onto the skin of the opposite flank. Where the CCM F-751 culture was rubbed onto the non-clipped and non-scarified skin, no satisfactory protection was obtained.

Examination by culture as well as microscopic examination of clinically affected animals yielded positive results.

Table 1.

Test of the protective potency of avirulent $T$. verrucosum CCM F-751 strain upon its epicutaneous inoculation in two doses. Challenge was carried out on the same site as was used for inoculation.

\begin{tabular}{|c|c|c|c|c|c|c|}
\hline \multirow[t]{2}{*}{$\begin{array}{l}\text { Mode of } \\
\text { immunization }\end{array}$} & \multirow[t]{2}{*}{$\begin{array}{l}\text { Calf } \\
\text { No. }\end{array}$} & \multicolumn{5}{|c|}{$\begin{array}{l}\text { Skin mycotic changes after challenge, } \\
\text { days after challenge }\end{array}$} \\
\hline & & 14 & 19 & 24 & 28 & 33 \\
\hline $\begin{array}{l}\text { Non-immu- } \\
\text { nized } \\
\text { controls }\end{array}$ & $\begin{array}{l}41151 \\
41235 \\
42371 \\
86534 \\
86656 \\
86659 \\
86684 \\
86768 \\
86782 \\
\end{array}$ & $\begin{array}{r}+ \\
+ \\
++ \\
+ \\
++ \\
+ \\
+ \\
+\end{array}$ & $\begin{array}{r}+++ \\
+++ \\
+++ \\
+ \\
+++ \\
+++ \\
+ \\
\pm \\
++\end{array}$ & $\begin{array}{l}+++ \\
+++ \\
+++ \\
+++ \\
+++ \\
+++ \\
+++ \\
+ \\
+++\end{array}$ & $\begin{array}{l}+++ \\
+++ \\
+++ \\
+++ \\
+++ \\
+++ \\
+++ \\
+ \\
+++\end{array}$ & $\begin{array}{l}+++ \\
+++ \\
+++ \\
++ \\
+++ \\
+++ \\
+++ \\
++ \\
+++\end{array}$ \\
\hline $\begin{array}{l}\text { Onto } \\
\text { clipped, } \\
\text { gently } \\
\text { scarified } \\
\text { skin }\end{array}$ & $\begin{array}{l}41096 \\
41098 \\
41169 \\
86627 \\
86767 \\
86769 \\
86801 \\
86806 \\
86807 \\
\end{array}$ & $\begin{array}{r} \pm \\
\pm \\
+t \\
\pm \\
\pm \\
\pm \\
+ \\
+ \\
+\end{array}$ & $\begin{array}{l} \pm \\
- \\
+ \\
- \\
+ \\
\pm \\
- \\
\pm \\
+\end{array}$ & $\begin{array}{l} \pm \\
- \\
- \\
\overline{+} \\
- \\
- \\
\overline{ \pm}\end{array}$ & $\begin{array}{l}\bar{z} \\
\bar{z} \\
\bar{z} \\
\bar{z}\end{array}$ & $\begin{array}{l}\overline{ } \\
\bar{z} \\
\bar{z} \\
\bar{z} \\
\bar{z} \\
\overline{-}\end{array}$ \\
\hline $\begin{array}{l}\text { Onto } \\
\text { clipped } \\
\text { non-scarified } \\
\text { skin }\end{array}$ & $\begin{array}{l}41168 \\
86530 \\
86663 \\
86802 \\
86804 \\
86805 \\
86808 \\
86828 \\
86829 \\
86836 \\
\end{array}$ & $\begin{array}{l} \pm \\
\pm \\
- \\
+ \\
\pm \\
\pm \\
+ \\
+ \\
\pm \\
\pm\end{array}$ & $\begin{array}{l}+ \\
+ \\
+ \\
+ \\
\pm \\
+ \\
+ \\
+ \\
+\end{array}$ & $\begin{array}{l} \pm \\
- \\
- \\
\pm \\
\pm \\
- \\
- \\
\pm \\
- \\
-\end{array}$ & $\begin{array}{l} \pm \\
- \\
- \\
\pm \\
\pm \\
- \\
- \\
- \\
-\end{array}$ & $\begin{array}{l}\bar{z} \\
\bar{z} \\
\overline{ \pm} \\
\bar{z} \\
\bar{z} \\
\bar{z}\end{array}$ \\
\hline $\begin{array}{l}\text { Onto } \\
\text { non-clipped } \\
\text { non-scarified } \\
\text { skin }\end{array}$ & $\begin{array}{l}41202 \\
86842 \\
86843 \\
86844 \\
86845\end{array}$ & $\begin{array}{r}+ \\
+ \\
+ \\
+ \\
+\end{array}$ & $\begin{array}{r}+ \\
++ \\
++ \\
+ \\
+\end{array}$ & $\begin{array}{l}+ \\
+ \\
++ \\
++ \\
+\end{array}$ & $\begin{array}{r}+ \\
+ \\
+ \\
+ \\
+\end{array}$ & $\begin{array}{l} \pm \\
+ \\
+ \\
++ \\
-\end{array}$ \\
\hline
\end{tabular}

Explanatory notes to Tables 1 and 2

- $\quad$ No dermal mycotic changes.

$\pm \quad$ Minute dermal changes - scales, papillae.

$+\quad$ Solitary mycotic foci.

+ Mycotic foci covering more than a quarter of the inoculated area.

++ Mycotic foci covering more than half of the inoculated area. 
Table 2.

Test of the protective potency of avirulent $T$. verrucosum CCM F-751 strain upon its epicutaneous inoculation in two doses. Challenge was carried out on the oppoette side of the body than was used for inoculation.

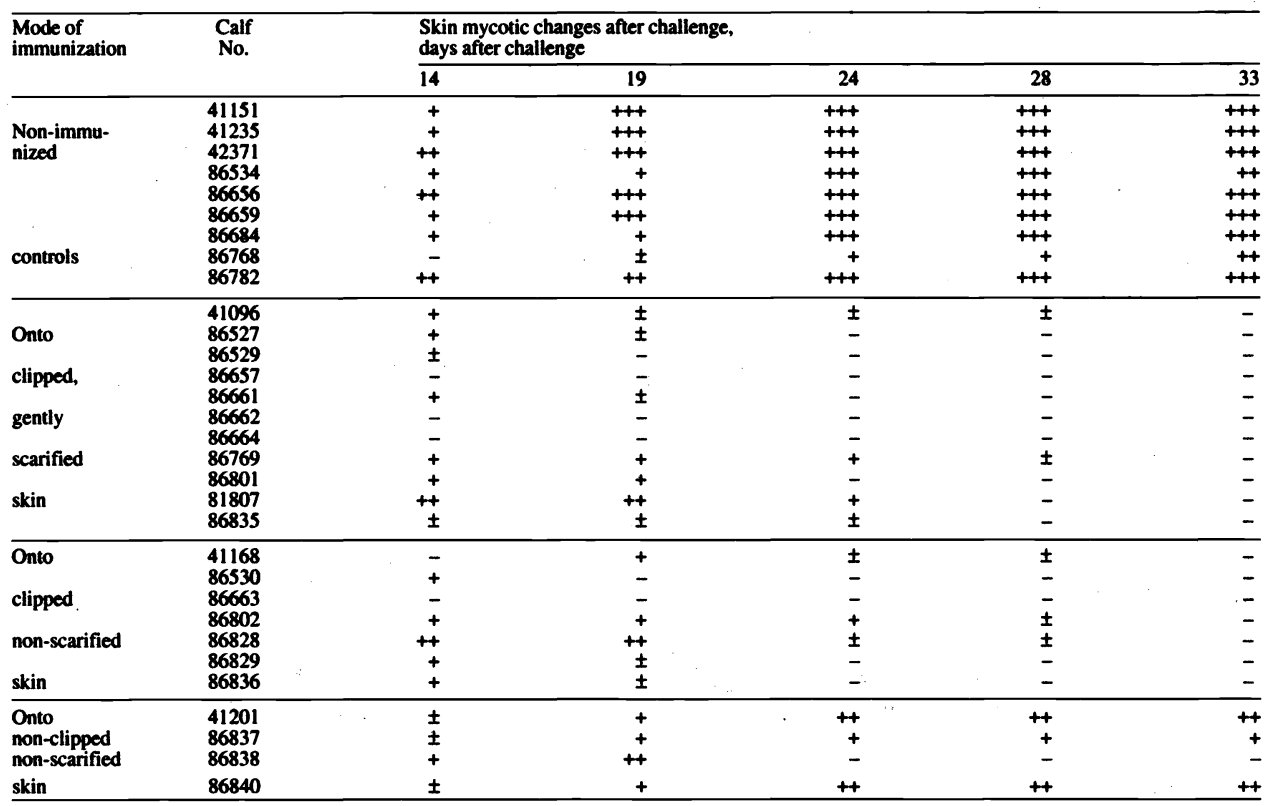

\section{Discussion}

The development of immunity against dermatophyte infection after previous primary dermatophytosis was demonstrated by a number of writers (Grappel et al. 1974). The main role in the defence of the host against dermatophytes has generally been ascribed to cell-mediated immunity (Svejgaard 1986). The mechanisms involved in these reactions are still the subject of investigation (Calderon 1989; Jones 1993). Experiments along this line have been made with various animal species and and dermatophyte cultures. Some investigators (Lepper 1972; Wawrzkiewicz and Ziolkowska 1979) studied the immune processes in cattle infected with $T$. verrucosum cultures. Our experiments, too, were carried out on calves. In contrast to the afore-mentioned writers we tried to induce the immune response of the animals by contact with living avirulent $T$. verrucosum antigen.

Although our experimental calves inoculated epicutaneusly with two doses of avirulent $T$. verrucosum CCM F-751 strain did not develop trichophytosis, they became resistant to experimental infection with the virulent $T$. verrucosum strain. However, the immunization proved successful only in those animals that were inoculated with the immunogenic CCM F-751 culture onto the clipped skin. The result did not depend upon the fact whether the clipped skin was scarified or not.

The mode of immunization used in our experiments was not only limited to the development of local immunity; resistance to experimental infection was found also on the opposite side of the body. This is in keeping with the development of resistance in cattle infected experimentally with a virulent $T$. verrucosum culture; animals that recovered from trichophytosis were reported to show resistance to reinfection on the previously infected sites as well as in other places of the body (Kielstein 1968; Lepper 1972). 
Where the avirulent $T$. verrucosum culture was rubbed onto the intact hair of the calves, no solid degree of immunity against experimental infection was produced. Owing to the rather thick hair of the animals, the amount of elements of the avirulent strain that reached the skin surface was not sufficiently immunogenic.

It seems probable that the principle of the development of immunity against trichophytosis, recorded by us after epicutaneous administration of avirulent CCM F-751 strain, may be valid also in the field. The possibility that healthy animals can carry a living $T$. verrucosum culture in their hair and skin has been demonstrated (Ko márek and Ś tros 1979). Where low-virulence strains are involved, the presence of such inapparent carriers may not endanger susceptible animals in the herd and may even stimulate their increased resistance to trichophytosis.

\section{Vznik imunity proti trichofytóze po epikutánní aplikaci avirulentního kmene Trichophyton verrucosum}

Po dvourázové epikutánní aplikaci avirulentního kmene Trichophyton verrucosum do ostříhané skarifikované nebo i neskarifikované pokožky došlo u telat ke vzniku imunity proti experimentální infekci virulentním kmenem téhož druhu. Chráněnost telat, kterým byla imunogenní kultura $T$. verrucosum vetřena do srsti neostřihané pokožky, nebyla dostatečná.

\section{Возникновение иммунитета к трихофитозу после эпикутанного ввода авирулентного штамма Trichophyton verrucosum}

После двукратного эпикутанного ввода авирулентного штамма Trichophyton verrucosum в стриженную скарифицированную или не скарифицированную кожу у телят возник иммунитет к экспериментальной инфекции вирулентным штаммом того же вида. Защищенность телят, которым иммуногенную культуру $T$. verrucosum втирали в шерсть нестриженной кожи, была недостаточной.

References
BLOCH, B.-MASSINI, R.: Studien über Immunität und Überempfindlichkeit bei hyphomyzetenerkrankungen. Z. Hyg. Infektkrankh., 36, 1909: 68-69.

CALDERON, R. A.: Immunoregulation of dermatophytosis. CRC Crit. Rev. Microbiol., 16, 1989: 339-368.

GRAPPEL, S. F.-BISHOP, C. T.-BLANK, F.: Immunology of dermatophytes and dermatophytosis. Bacteriol. Rev., 38, 1974: 222-250.

HEJTMÁNEK, M.-WEIGL, E.-HEJTMÁNKOVÃ, N.: Mutants of Trichophyton verrucosum. Acta Univ. Palacki. Olomuc. (Olomouc), Fac. Med., 114, 1986: 149-164.

JONES, H. E.: Immune response and host resistance of humans to dermatophyte infection. J. Am. Acad. Dermatol., 28, 1993: S12-S18.

KIELSTEIN, P.: Immunologische Untersuchungen während der spontanen und experimentellen Rindertrichophytie. Wiss. Z. Karl Marx Univ. Leipzig, 17, 1968: 177-178.

KOMÁREK, J.-STROS, K.: Zkušenosti s vakcinací skotu proti trichofytóze v CSR v letech 1976-1978. Veterináství, 29, 1979: 540-541.

LEPPER, A. W. D.: Experimental bovine Trichophyton verrucosum infection. Preliminary clinical, immunological and histological observations in primarily infected and reinoculated cattle. Res. vet. Sci., 13, 1972: 105-115.

RYBNIKÁR̆, A.: Cross-immunity in calves after vaccination against trichophytosis. Acta vet. Brno, 61, 1992: 189-194.

SVEJGAARD, E.: Recent trends in the immunology of dermatophytosis. Microbiol. Sci., 3, 1986: 154-159.

WAWRZKIEWICZ, K.-ZIOLKOWSKA, G.: Immunological response in guinea-pigs and calves infected experimentally with Trichophyton verrucosum. Mykosen, 22, 1979: 314-324.

WEIGL, E.: Immunologie u dermatofytóz. Čs. Epidem., 36, 1987: 308-319. 